\title{
APONTAMENTOS SOBRE O PROBLEMA DA RECEPÇÃO ESTÉTICA NOS MUSEUS DE ARTE A PARTIR DE THEODOR ADORNO
}

Nivaldo Alexandre de Freitas

É um fato evidente que a educação e a cultura pensadas como elementos para a emancipação do indivíduo têm sido depreciadas intencionalmente, de um lado pelas esferas do poder que conduzem políticas abrangentes para essas áreas, e por outro, pela indústria cultural que ajuda, como meio poderoso que é, a promover o que resta de espiritual a simples mercadoria a ser vorazmente consumida.

Em uma época em que a racionalidade tecnológica invade todas as esferas da vida social, provocando um desapreço às artes e às ciências que não possuem uma aplicação imediata, uma visita às obras de um museu se torna tarefa de excêntricos, salvo, é claro, quando se trata de megas exposições, com o toque da mídia de massa, em que apilhados, os visitantes recebem à entrada um fone de ouvido com o qual, ao longo da visita, ele obtém todos os 'dados' relativos às obras, senão uma interpretação já pronta delas, retirando-lhe o trabalho da recepção.

A visita ao museu, reservada aos momentos de lazer, não visa cansar o visitante com reflexões excessivas, mas entretê-lo com obras de uma beleza que lhe é suspeita e fornecer-lhe, junto com o bilhete de entrada, a certeza de que está em dia com a tradição cultural recomendada a qualquer sujeito que não quer passar por 'desinformado'.

Esse estado de coisas mostra o quanto atual é o velho conceito marxista de fetiche da mercadoria. A obra de arte passa a ter um valor de uso e um valor de troca. Se antes a arte oferecia alguma resistência aos fins do mercado, hoje ela se destina ao entretenimento e não é mais admitida como algo sem finalidade.

Mas a arte não se cala diante dessa situação, já que a arte contemporânea, fechada em sua linguagem própria, segundo o processo de racionalização social que apenas se acentua, tenta resistir ao consumo fácil e não sem dificuldades alguém visita uma exposição de arte atual.

É nessa aporia que se encontra o museu hoje, e num ensaio de 1953, Theodor Adorno (1903 - 1969), representante da chamada Escola de 
Frankfurt, já apontava essa dificuldade e teorizou sobre ela. Trata-se do ensaio denominado Museu Valéry Proust. 1

Diz Adorno que os museus são como sepulcros de obras de arte e testemunham a neutralização da cultura. Neles, as obras são conservadas mais por motivos históricos, e menos por uma necessidade do presente, a de mostrar aos homens, por exemplo, como eles se afastam da possibilidade de realização da humanidade e da felicidade.

A alternativa ao museu seria expor a obra em seu ambiente natural (Adorno se refere a arte anterior ao século XX e pensa, claro, na situação européia), mas essa reposição da obra em contato com a vida imediata revela algo de desamparo e um certo rancor reacionário, já que uma obra deveria levar o receptor muito além do simples espaço em que ela própria se encontra. Além disso, a impossibilidade de formar coleções particulares faz com que a felicidade da contemplação dependa dos museus.

Todavia, o questionamento central de Adorno é sobre a validade de se afirmar alguma 'tradição cultural' que os museus possam representar, numa época em que arte é transformada em mercadoria, mas ao mesmo tempo, renunciar à possibilidade de experienciar o tradicional também implica em capitular à barbárie por uma pura fidelidade à cultura. Adorno logo admite que não há solução para esse impasse, já que é o próprio mundo que se encontra fora dos eixos, mas também não basta reconhecer essa situação negativa: é preciso discuti-la com argumentos específicos. Para tanto, Adorno põe em cena a reflexão de dois escritores que conheciam intimamente o processo artístico, mas com posições contrárias em relação aos museus. São os franceses Paul Valéry e Marcel Proust. ${ }^{2}$

A visão desses autores sobre a questão dos museus aprofunda, de um lado, o problema do fetichismo na arte, representado pela preocupação excessiva de Valéry quanto à consistência imanente da obra e a contingência do sujeito diante dela, e por outro lado, o problema da subjetividade excessiva e presunçosa, representado por Proust, que vê na arte elementos de si próprio, desconsiderando os elementos objetivos da obra.

\footnotetext{
1 Theodor W. Adorno, Prismas - crítica cultural e sociedade, Ática, 1998.

2 Segundo Adorno, o artigo de Valéry sobre esse tema intitula-se Le problème dês musées, e se encontra no volume de ensaios Pièces sur l'art. As reflexões de Proust encontram-se no terceiro volume de A l'ombre dês jeunes filles em fleurs. In Theodor W. Adorno, Prismas..., p.174.
} 


\section{Paul Valéry e o apego à objetividade}

A posição de Valéry antecipa algo que seria uma questão importante para a atualidade, a questão do objetivo da visitação ao museu. A partir do momento em que a obra é retirada do seu lugar de origem e colocada no museu, acaba por haver um motivo para visitá-lo, que pode ser pela instrução, a busca de encantamento, o cumprimento de um dever ou a satisfação de uma convenção. Quem poderia hoje cometer o pecado de ir a Paris sem visitar o Louvre? Mas lá presente o visitante buscaria o quê? É possível o encantamento em meio à fria confusão, à desordem ordenada das grandes exposições? O fato é que com a proliferação dos museus, que passaram a ser os abrigos oficiais das artes plásticas, a relação entre arte e sociedade se alterou. Valéry procura captar e refletir esse momento. Sabe-se que as instituições dizem muito acerca da sociedade que delas necessita. Da mesma forma que podemos perceber uma sociedade manicomial, que não tolera a diferença, pelos seus mecanismos de exclusão da loucura em hospitais psiquiátricos, não seriam os museus, numa sociedade que despreza a cultura e a tradição, locais de sua clausura?

Segundo Valéry, a obra no museu perde sua característica de exemplar único; um quadro mata os outros ao seu redor; o homem empobrece pelo excesso de suas riquezas. Adorno diz que Valéry, alheio a qualquer elemento de economia, registra em seus nervos estéticos a falsa riqueza e aborda precisamente a superacumulação.

Pode-se ainda pensar que na sociedade em que se acelera o passo da reificação, em que o trabalho, cada vez mais dominado pela razão tecnológica se torna por isso mais alienado, privando o sujeito de experiências formadoras, a arte seria justamente a esfera social que guardaria a possibilidade de alguma experiência. Mas visita-se o museu e se relaciona com as obras como com as peças da linha de produção: o tempo da visita é aquele da divisão social do trabalho, não aquele que pode ser único na relação entre uma obra e o observador.

Valéry aponta para uma crescente superficialidade na relação com a obra; a arte passa a ser assunto de educadores (hoje a famigerada arteeducação) e uma gama de informações passam a ser a ela relacionadas. A arte no museu se transforma em documento histórico e a erudição assim obtida seria a derrota da cultura, sinal de ignorância.

As obras do passado se tornaram órfãs nos museus, órfãs da mãe arquitetura, aquela que lhes davam espaço, uma luz bem definida, seus temas e suas alianças. 


\section{Marcel Proust e o exagero da subjetividade}

Para Proust, o museu interessa justamente por afastar seu visitante do contexto superficial dos objetos da atividade prática. O essencial para ele é o ato do espírito que isolou as obras de seu ambiente original. É no salão do museu que a obra permite uma alegria inebriante e se mostra nua e sóbria de todos os seus detalhes circundantes, expondo os espaços interiores onde o artista se recolhe para criar.

Adorno diz que a atitude de Proust com a arte é a do amador, não a do especialista, pois para ele a arte começa em sua vida póstuma, descolada de seu contexto; o amador é o único que pode passear pelo museu e questionar categorias da arte que o expert não questiona, o que faz desse último mais ingênuo em relação a arte como um todo.

Proust rompe com o fetichismo na medida em que ele considera a arte como algo de diferente, como um pedaço da vida do próprio observador, um elemento de sua consciência. Nada para ele tem consistência se não foi transmitido pela memória. Proust se apega à segunda vida da obra, deslocada de seu contexto, exatamente pela ligação com a memória. A qualidade estética lhe é secundária. $\mathrm{O}$ olhar subjetivo, pautado na memória, rompe o véu da cultura, invade as distinções estéticas e desperta as obras do museu para a vida. Somente assim, deslocando-as de seu contexto, elas ganham espontaneidade.

Ora, mas quem estaria, então, com a razão? O importante desse jogo de argumentos em que Adorno coloca Valéry contra Proust é o fato de que a disputa não resulta em vencedores, mas sim para um desdobramento de uma contradição em que ambos os autores possuem momentos de verdade. Isso conduz a um olhar menos ingênuo ao museu e às obras que ele abriga. Diz Adorno que a fetichização do objeto e a presunção do sujeito corrigem-se mutuamente.

Enquanto Valéry é incorruptível no sentido de não tolerar as mudanças que trazem consigo a regressão do espírito, Proust dá o primado à experiência e não tolera nada rígido. Adorno aponta que há em Proust passagens de um desenfreado subjetivismo que transforma a obra em uma bateria de testes projetivos, de forma que se pode nela enxergar o que o sujeito desejar. Ele pensa em favor dos museus, mas a partir do homem, não a partir da obra. Para Valéry, em sua postura fetichista, em seu apego à pura objetividade, a obra possui elementos irredutíveis à subjetividade do observador. Proust superestima o ato de liberdade na arte, pois ela exige objetividade, com uma lógica e coerência própria. Mas a deslealdade da 
subjetividade livre em relação ao objetivo o habilita a romper com a imanência da cultura.

Tal aporia aponta para a necessidade de manter sempre no horizonte da contemplação estética todas essas dificuldades, tratando a obra como um 'campo de força', diz Adorno, em que a obra não permita qualquer olhar, mas também que o observador não se acorrente às categorias tradicionais da arte e possa dar a obra vida nova. Um certo fetichismo é necessário, diz Adorno, pois apenas escapa de uma relação vazia com a obra aquele que, fazendo uso de um princípio de seleção, escolhe duas ou três obras e as toma como ídolos.

\section{O museu de arte contemporânea e a sublimação}

Todavia, se neste ensaio de 1953 adorno se esforça em apontar a dificuldade da relação entre obra e receptor, mesmo partindo de observadores nada ingênuos, como Proust e Valéry, em outros ensaios Adorno irá fazer uso de conceitos da psicanálise freudiana para mostrar como as dificuldades dessa relação atingem as dimensões pulsionais do sujeito.

O conceito de sublimação, por exemplo, é criticado por Adorno 3 por não representar mais a dinâmica pulsional tanto do artista criador, como do receptor.

Se para Freud o impulso que move o indivíduo para a arte é uma pulsão que não pôde atingir uma satisfação motora real, mas que se dirige para realizações socialmente desejáveis, para Adorno, que pensava principalmente a arte do século XX, a sublimação talvez nem sequer exista, pois dificilmente o artista sublima, uma vez que as artes legítimas são aquelas que são socialmente indesejadas.

Adorno questiona a descrição freudiana do destino do impulso artístico, mas não desiste de buscar as bases psíquicas do fenômeno artístico no conceito de pulsão, e para tanto pensa em um novo conceito de expressão. Assim, a expressão é sugerida como uma moção pulsional violenta que aparece livremente, contornando o princípio de realidade, mas, ao mesmo tempo, sem o subjetivo negar a própria realidade, colidindo com ela. Tal moção não encontra objeto claramente definido, seu caráter é informe: sua quota é muito mais uma ausência de inibição, excessiva e histérica,

${ }^{3}$ Theodor W. Adorno, Minima Moralia, 1993. 
ultrapassando todas as angústias imaginárias; é um narcisismo impelido até os limites da paranóia. $^{4}$

A expressão expõe o peso da realidade sem se acomodar a ela, o que não é fácil para o artista que permanece desamparado diante de uma expressão que foi além de sua própria psicologia. Isso põe em dúvida a inserção da obra de arte entre as realizações culturais: ela pertence à cultura, mas também a recusa com sua simples existência: na renúncia ao objetivo pulsional a arte continua fiel a este, com uma fidelidade que desmascara o que é socialmente desejado, ingenuamente glorificado por Freud como a sublimação que, provavelmente, não existe. ${ }^{5}$

Assim, ao se falar de arte da atualidade - que sem dúvida necessita do museu para sua manifestação, quando não o utiliza como material - é preciso pensar uma arte que está longe do prazer, tanto do lado do artista como do receptor. Para aquele que visita um museu de arte contemporânea, o que lhe espera são exposições trabalhosas em relação à recepção e pouco prazerosas, já que as obras negam o estado falso do mundo em que elas nascem. Somente aquele que está convicto do que quer e não espera lazer ou prazer vulgar no espaço do museu pode terminar sua visita um pouco menos frustrado com as obras e um pouco mais estarrecido com o mundo.

\section{Bibliografia}

ADORNO, T. W. Minima Moralia - Reflexões a partir da vida danificada. São Paulo: Ática, 1993.

. Prismas: Crítica Cultural e Sociedade. São Paulo: Ática, 1998.

\footnotetext{
${ }^{4}$ Ibidem, p.186.

${ }^{5}$ Ibidem.
} 